\title{
Streptomycetes antagonism against Cladosporium fulvum Cooke and Fusarium oxysporium f.sp. lycopersici
}

\author{
Antagonismo de estreptomicetos a Cladosporium fulvum Cooke e Fusarium oxysporium \\ f.sp. lycopersici
}

Ana Cristina Fermino Soares ${ }^{\mathrm{I}}$ Carla da Silva Sousa ${ }^{\mathrm{II}}$ Marlon da Silva Garrido ${ }^{\mathrm{II}}$

\section{- NOTE -}

\begin{abstract}
This research aimed to evaluate the secondary effects of secondary metabolites produced by streptomycetes on spore germination and mycelial growth of the phytopathogenic fungi Cladosporium fulvum Cooke and Fusarium oxysporium $f$. sp. lycopersici from tomato plants. Metabolites produced by streptomycete isolates codified as AC147 and AC-92 caused $94.1 \%$ inhibition of $C$. fulvum while AC-95 isolate caused $33.9 \%$ inhibition. AC-92 was the most efficient for $\boldsymbol{F}$. oxysporum $f$. sp. lycopersici, causing $94.2 \%$ inhibition of spore germination. For mycelial growth, AC-26 and AC-92 were the most efficient in inhibiting C. fulvum growth by $46.6 \%$ and $\mathbf{F}$. oxysporum $f$. sp. lycopersici by $29.9 \%$. These streptomycetes are potential agents for biocontrol development methods of these tomato plant pathogenic fungi.
\end{abstract}

Key words: biocontrol, actinomycetes, secondary metabolites.

RESUMO

Este trabalho teve como objetivo avaliar o efeito de metabólitos secundários produzidos por estreptomicetos na germinação de esporos e no crescimento micelial dos fungos Cladosporium fulvum Cooke e Fusarium oxysporum sp. f. lycopersici da cultura do tomateiro. Metabólitos produzidos pelos isolados AC-147 e AC-92 causaram 94,1\% de inibição da germinação de esporos de $\boldsymbol{C}$. fluvum, enquanto que o isolado AC-95 causou 33,9\% de inibição. O AC-92 foi o mais eficiente para $\boldsymbol{F}$. oxysporum $f$. sp. lycopersici, causando $94,2 \%$ de inibição na germinação de esporos. Para o crescimento micelial, AC-26 e AC-92 foram os mais eficientes na inibição dos fungos C. fulvum, em 46,6\%, e F. oxysporum f. sp. Lycopersici, em 29,9\%. Esses estreptomicetos são potenciais agentes para o desenvolvimento de métodos de controle biológico desses fungos fitopatogênicos do tomateiro.

Palavras-chave: biocontrole, actinomicetos, metabólitos secundários.

Tomato (Lycopersicum esculentum Mill) is an important crop grown in Brazil. However, Cladosporium leaf mold, caused by Cladosporium fulvum Cooke, is one of the principal leaf diseases in humid regions and in green-house conditions (AGRIOS, 2005). This disease is characterized by the appearance of yellowish green spots on older leaves, which enlarge and coalesce. These spots turn brown to black, spread to the remaining younger leaves, and may cause defoliation and losses in tomato productivity (AGRIOS, 2005). Another disease of great economic importance is Fusarium wilting, caused by Fusarium oxysporium f. sp.lycopersici, which attacks tomato root system, causing necrosis of stem tissues, yellowing of old leaves, wilting and plant death (FILGUEIRA, 2000).

Fusarium wilting is a soil borne disease, of difficult control, which t remains indefinitely in the

'Universidade Federal do Recôncavo Baiano, Centro de Ciências Agrárias, Ambientais e Biológicas, Cruz das Almas, BA, Brasil.

IIDepartamento de Energia Nuclear, Universidade Federal de Pernambuco (UFPE). Av. Prof. Luiz Freire, 1000, Bairro Cidade Universitária, 50741-110, Recife, PE, Brasil. E-mail: cssagro@yahoo.com.br. *Autor para correspondência. 
infested. On the other hand, Cladosporium diseases can be controlled by sanitation and application of fungicides (AGRIOS, 2005). Yet, biological control has been widely studied as an alternative method of controlling plant diseases, since the increasing use of fungicides has caused development of pathogen resistance, problems with environment pollution, and human and animal health risks (COMPANT et al., 2005).

The actinomycetes, mainly those belonging to the Streptomyces genus, make up an important group of soil bacteria from the actinobacteria class. Several species of the Streptomycetaceae family have been widely studied because of their capacity for producing secondary metabolites, such as antibiotics and extracellular enzymes (INBAR et al., 2005). In addition, these microorganisms act in the degradation of complex organic molecules as well as recalcitrant substances, especially cellulose, lignocellulose, xylan and lignin, therefore, playing an important role in soil organic matter decomposition (DING et al., 2004).

The capacity of Streptomyces spp. to control mycelium growth of Fusarium moniliforme isolated from corn seeds was observed by BRESSAN \& FIGUEIREDO (2003b). Actinomycetes have also been reported by CAO et al. (2005) to control Fusarium oxysporum f. sp. cubense in vitro and in banana plants grown in pots. Metabolites produced by streptomycete isolates in media growth culture were also effective in controlling mycelium growth and spore germination of Coletotrichum gloeosporioides and Curvularia eragrostides isolated from yam (Dioscorea cayennensis Lam) leaf spots (SOARES et al., 2006). Actinomycetes also play an important role in the control of parasitic nematodes plants (SOUSA et al., 2006; COIMBRA et al., 2005). This work aimed to evaluate the effect of secondary metabolites produced by six streptomycete isolates on spore germination and mycelium growth of the phytopathogenic fungi $\boldsymbol{C}$. fulvum and F. oxysporium f. sp. lycopersici.

Six streptomycete isolates, with the identification codes AC-29, AC-92, AC-95, AC-103, AC26 , and AC-147 were tested. These isolates are part of the culture collection from the Phytopathology and Soil Microbiology laboratory of the Federal University of Recôncavo, in the State of Bahia, Brazil, and were isolated from soil by LIMA (2002). They were grown in solid argenine glycerol agar (AGS) culture medium, at $28^{\circ} \mathrm{C}$, for 10 days. After this growth period, $10 \mathrm{ml}$ of distilled sterile water was added aseptically to each Petri plate with the grown streptomycete cultures and the plates were incubated at room temperature $\left(26 \pm 2^{\circ} \mathrm{C}\right)$ for 24 hours. The acquose metabolite suspensions obtained from the streptomycete cultures were transferred to $2.0 \mathrm{ml}$ Eppendorf tubes and centrifuged at 12000rpm (centrifuge Cientec, model 1500, São Paulo, Brazil), for 15 minutes. After centrifugation, the supernatant was removed and filtered through a sterile Millipore nitrocellulose membrane $(0.22 \mu \mathrm{m}$ porosity), in order to obtain a free cell metabolite suspension. The metabolite suspensions were transferred to small sterile glass bottles and kept at $-4^{\circ} \mathrm{C}$.

Cladosporium fulvum Cooke and Fusarium oxysporum f.sp. lycopersici were isolated from tomato plants with leaf spot disease and wilting symptoms respectively, in the municipality of Cruz das Almas, State of Bahia, Brazil, and preserved in small glass bottles with sterile water. These cultures were transferred to Petri plates with potato dextrose agar culture medium (PDA) and incubated at $28 \pm 2^{\circ} \mathrm{C}$, for eight days. After incubation, $5 \mathrm{ml}$ of sterile distilled water was added to each plate, under aseptic conditions, and the fungus colonies were scrapped with a flamed inoculating loop. The suspension was filtered in cheesecloth and the spore concentration was determined by counting under a light microscope with a Newbauer chamber, and was adjusted with sterile distilled water to a final concentration of $10^{5}$ spores $\mathrm{mL}^{-1}$.

Forty microliters of the metabolite suspension and $40 \mu$ of the fungal spore suspension were transferred to a microscope slide with three wells. The microscope slides were incubated at room temperature $\left(28 \pm 2^{\circ} \mathrm{C}\right)$ in a growth chamber prepared with Petri plates with wet filter paper at the bottom, and covered with plastic wrap. After fourteen hours of incubation, spore germination was paralyzed with the addition of one drop of lactophenol blue, and the germinated and non-germinated spores, from a total of 200 spores, were counted on the slide, under a light microscope at $40 \mathrm{X}$ magnification. This period of incubation (14 hours) was determined on observations and estimations of spores numbers germinated in the control treatment, for both fungi. The adequate incubation period was considered by the time at which the majority of the fungal spores had germinated in the control treatment. Spores which had their germinating tube with a length of at least $50 \%$ greater than the normal spore size were considered germinated.

The experimental design was completely randomized, in a factorial scheme $7 \times 2$ (six streptomycete isolates + control treatment $\mathrm{x} 2$ phytopathogenic fungi), with four replications. The control treatment was prepared with sterile water instead of the metabolite suspension. The percentage of germinated spores was calculated and the data was transformed in $\operatorname{arcsen} \sqrt{x / 100}$ for mean comparison by the test of Scott e Knott at a level of $5 \%$ probability. 
To evaluate the effect of the metabolites produced by the streptomycetes on mycelial growth of both fungi (MARIANO \& SILVEIRA, 2005), an assay was conducted in an entirely randomized experimental design, in a factorial scheme 7 × 2 (six streptomycete isolates + control treatment $\times 2$ phytopathogenic fungi), with four replications. Ten milliliter aliquots of the metabolites were transferred to Erlenmeyer flasks with $90 \mathrm{ml}$ of melting PDA medium. The media growth with the metabolites was poured into sterile Petri plates $(20 \mathrm{ml}$ per plate). After solidification of the media growth a disc ( $7 \mathrm{~mm}$ in diameter) of an 8 day old fungus culture (C. fulvum Cooke or $\boldsymbol{F}$. oxysporum f.sp.lycopersici, grown in PDA at room temperature) was cut from the borders of the culture and transferred to the center of the plate. The control treatment consisted of a disc of the fungus culture transferred to the center of a plate with PDA medium without the streptomycete metabolites. The cultures were incubated at room temperature $\left(26 \pm 2^{\circ} \mathrm{C}\right)$. Mycelium growth was daily measured with a ruler. The data was analyzed by the variance analysis (ANOVA) and the test of Scott \& Knott, at a level of $5 \%$ probability.

Isolates AC-92 and AC-147 caused 94.1\%, and isolate AC-26 caused $90.9 \%$ inhibition of $C$. fulvum spore germination $(\mathrm{P} \leq 0,05)$, when compared with the control treatment. Isolates AC-103, AC-29, and AC-95, inhibited spore germination by $83.9 \%, 79.7 \%$ and $56.7 \%$, respectively (Table 1). The metabolites produced by isolates AC-92, AC-103, AC-147, AC-95, AC-29, and AC26 inhibited spore germination of $\boldsymbol{F}$. oxysporum f. sp. lycopersici by $94.2 \%, 71.2 \%, 66.5 \%, 68.6 \%, 53.5 \%$, and
$49.1 \%$ respectively, when compared with the control treatment (Table 1).

The metabolites produced by AC-26, AC92, and AC-147 were the most efficient in inhibiting spores germination of $C$. fulvum, while the metabolites produced by AC- 92 were the most efficient in inhibiting spore germination of both phytopathogenic fungi evaluated, causing over $90 \%$ inhibition of spore germination. Therefore, they could be promising isolates for biological control of Cladosporium and Fusarium diseases of tomato plants. Also, for Fusarium diseases, inhibition of spore germination can be considered a mechanism for disease control, since germ tube of spores or mycelium must penetrate the root for plant infection to occur. For Fusarium diseases, the effect of these metabolites on the viability and germination of chlamydospores should also be evaluated, due to their capacity to survive long periods in soil. EL-ABYAD et al. (1993), also obtained good results when evaluating the affect of filtered Streptomyces pulcher and Streptomyces canescens metabolites, in the reduction of spore germination, mycelial growth and sporulation of $\boldsymbol{F}$. oxysporum $\mathrm{f}$. $\mathrm{sp}$. lycopersici, Verticillium albo-atrum, and Alternaria solani, all tomato plant pathogens.

Metabolites produced by isolate AC-26 inhibited mycelial growth of the $\boldsymbol{C}$. fulvum Cooke by $46.6 \%$, in comparison to the control treatment (Table 1). The other treatments presented significant differences when compared to the control, although with a lower percentage of mycelial growth inhibition (13.0 to $19.1 \%$ ). Also, an inhibitory effect of $29.9 \%$ was

Table 1 - Effect of secondary metabolites produced by six isolated streptomycetes in the germination of spores (G.S.) and mycelial growth (M.G.) of the fungus $\boldsymbol{C}$. fulvum and $\boldsymbol{F}$. oxysporium f. sp. lycopersici.

\begin{tabular}{|c|c|c|c|c|c|c|c|c|}
\hline \multirow{2}{*}{ Isolated streptomycetes } & \multicolumn{2}{|c|}{-------C. fulvum------. } & \multicolumn{2}{|c|}{-----F. oxysporum----- } & \multicolumn{2}{|c|}{--------C. fulvum------- } & \multicolumn{2}{|c|}{-----F. oxysporum----- } \\
\hline & G.S. $(\%)$ & $* \mathrm{I} .(\%)$ & G.S. $(\%)$ & I. $(\%)$ & M.G.(mm) & I. $(\%)$ & M.G.(mm) & I. $(\%)$ \\
\hline Control treatment & $78.3 \mathrm{Aa}$ & - & 71.9Aa & - & $89.0 \mathrm{aA}$ & - & $89.3 \mathrm{aA}$ & - \\
\hline AC-26 & 7.1Bd & 90.9 & $36.6 \mathrm{Ab}$ & 49.1 & $47.5 \mathrm{cB}$ & 46.6 & $86.9 \mathrm{bA}$ & 2.69 \\
\hline AC-29 & $15.9 \mathrm{Bc}$ & 79.7 & $33.4 \mathrm{Ab}$ & 53.5 & $76.2 \mathrm{bB}$ & 14.4 & $83.8 \mathrm{aA}$ & 6.16 \\
\hline AC-92 & 4.6Ad & 94.1 & 4.2Ad & 94.2 & $77.2 \mathrm{bA}$ & 13.2 & $65.2 \mathrm{aB}$ & 26.9 \\
\hline AC-95 & $33.9 \mathrm{Ab}$ & 56.7 & $22.6 \mathrm{Bc}$ & 68.6 & $78.0 \mathrm{bB}$ & 12.3 & $85.4 \mathrm{aA}$ & 4.37 \\
\hline AC- 103 & $12.6 \mathrm{Ac}$ & 83.9 & $20.7 \mathrm{Bc}$ & 71.2 & $74.7 \mathrm{bB}$ & 19.1 & $86.4 \mathrm{aA}$ & 3.25 \\
\hline AC-147 & 4.6Ad & 94.1 & $24.1 \mathrm{Bc}$ & 66.5 & $77.4 \mathrm{bB}$ & 13.0 & $87.2 \mathrm{aA}$ & 2.35 \\
\hline$* * \mathrm{CV}(\%)$ & \multicolumn{4}{|c|}{12.35} & \multicolumn{4}{|c|}{13.88} \\
\hline
\end{tabular}

Results followed by similar letters do not differ statistically, by the test of Scott e Knott at 5\% probability. Capital letters show a comparison of metabolites produced by the same streptomycete isolate for both fungi, while small letters show the comparison of all streptomycete isolates for the same fungi.

*I = Inibition

$* * \mathrm{CV}=$ Coefficient of Variation. 
observed for mycelial growth of $\boldsymbol{F}$. oxysporum f. sp. lycopersici, caused by metabolites produced by isolate AC-92. Studies with Streptomyces sp. have demonstrated the efficiency of these microorganisms for control of Fusarium moniliforme J. Sheldon (Giberella fujikuroi) (Sawada Wolen) mycelial growth, considered one of the main corn pathogens (Zea mays L.), which causes a reduction in seed germination, seedlings death, root rot, stalks and grain rot (BRESSAN \& FIGUEREDO, 2003b).

The effect of the secondary metabolites on spore germination and mycelial growth of the tested fungi, varied according to the streptomycete isolate. Besides the intrinsic differences that occurs among the species, other characteristics in the growth environment such as $\mathrm{pH}$, temperature and availability of nutrients, can interfere in the quantity as well as in the composition of the metabolites produced (GAVA, 1998), which can explain, in part, the metabolic diversity and the different degree of toxicity of the metabolites produced by the streptomycetes tested. The antimicrobial activity of the secondary metabolites produced by streptomycete species in the mycelial growth and spore germination of phytopathogenic fungi can be a result of the production of antibiotics and/or lythic enzymes, such as chitinases and glucanases produced by these microorganisms (BRESSAN \& FIGUEREDO, 2003a).

The in vitro potential of several streptomycete isolates to control tomato plant pathogenic fungi Cladosporium fulvum Cooke and Fusarium oxysporium f. sp. lycopersici, was demonstrated in the present work. Yet, further studies are necessary to evaluate the effect of these potential microbial agents to control tomato plant diseases under greenhouse and field conditions, and also to purify and characterize the secondary metabolites produced by these streptomycetes.

\section{REFERENCES}

AGRIOS, G. N. Plant pathology. Burlington, MA: Elsevier Academic, 2005. 922p.

BRESSAN, W.; FIGUEIREDO, J.E.F. Controle biológico de raças e isolados de Colletotrichum graminicola, do sorgo por actinomicetos. Sete Lagos:Embrapa Milho e Sorgo, 2003a. (Comunicado Técnico, n.62).

BRESSAN, W.; FIGUEIREDO, J.E.F. Controle Fusarium moniliforme em sementes de milho por actinomicetos. Sete Lagos: Embrapa Milho e Sorgo, 2003b. (Comunicado Técnico, n. 65).

CAO, L. et al. Isolation and characterization of endophytic streptomycete antagonists of Fusarium wilt pathogen from surface-sterilized banana roots. FEMS Microbiology Letters, v.247, n.2, p.147-152, 2005. Disponível em: <http:// www3.interscience.wiley.com/journal/118655703/abstract $>$. Acesso em: 24 mar. 2008. Doi: 10.1016/j.femsle.2005.05.006.

COIMBRA, J.L. et al. Efeito de exsudatos de colônias de Streptomyces sp. na mobilidade e mortalidade de Scutellonema bradys. Summa Phytopathologica, v.31, n.2, p.210-212, 2005 .

COMPANT, S. et al. Use of plant growth-promoting bacteria for biocontrol of plant diseases: principles, mechanisms of action, and future perspectives. Applied and Environmental Microbiology, v.71, n. 9, p.4951-4959, 2005. Disponível em: $<\mathrm{ht} \mathrm{tp}: / /$ a e m.as m.org/cgi/reprint/71/9/ 4951 ? maxtoshow $=\&$ HITS $=10 \&$ hits $=10 \&$ RESULTFO $\mathrm{R} \mathrm{M} \mathrm{A} \mathrm{T}=\&$ s e a r c h i d $=1 \&$ F I R S T I N D E X $=0$ $\&$ volume $=71 \&$ firstpage $=4951 \&$ resourcetype $=$ HWCIT $>$. Acesso em: 09 mar. 2008. Doi: 10.1128/AEM.71.9.4951-4959.2005.

DING, C.H. et al. High activity xilanase production by Streptomyces olivaceoviridis E-86. Wold Journal of Microbiology and Biotechnology, v.20, n.1, p.7-10, 2004. Disponível em: <http://www.springerlink.com/content/ tg48344p42468311/>. Acesso em: 02 jan. 2008. Doi: 10.1023/ B:WIBI.0000013278.24679.ed.

EL-ABYAD, M.S. et al. Towards the biological control of fungal and bacterial diseases of tomato using antagonistic Streptomyces spp. Plant and Soil, v.149, n.2, p.185-195, 1993. Disponível em: <http://www.springerlink.com/content/ w77743746q5171n5/>. Acesso em: 19 fev. 2008. Doi: 10.1007/ BF00016608.

FILGUEIRA, F.A.R. Manual de oleicultura: cultura e comercialização de hortaliças. 2.ed. São Paulo:Agronômica Ceres, 2000. 357p.

GAVA, C.A.T. Seleção de estreptomicetos para controle biológico de Ralstonia solanacearum e Erwinia carotovora. 1998. 114f. Dissertação (Mestrado em Agronomia) - Curso de Pós-graduação em Produção Vegetal, Universidade Federal Rural do Rio de Janeiro.

INBAR, E. et al. Competing factors of compost concentration and proximity to root affect the distribuition of Streptomycetes. Microbiology Ecology, v.50, n.1, p.73-81, 2005. Disponível em: < http://www.springerlink.com/content//r7247p871n14727/>. Acesso em: 04 abr. 2008. Doi: 10.1007/s00248-004-0111-x.

LIMA, J.L. Seleção de actinomicetos para o controle biológico de Ralstonia solanacearum e promoção de crescimento de mudas de tomateiro. 2002. $63 \mathrm{f}$. Dissertação (Mestrado em Ciências Agrárias) - Curso de Pósgraduação em Ciências Agrárias, Universidade Federal da Bahia.

MARIANO, R.L.R.; SILVEIRA, E.B. Manual de práticas em fitobacteriologia. 2.ed. Recife: Universidade Federal Rural de Pernambuco, 2005. 184p.

SOARES, A.C.F. et al. Soil streptomycetes with in vitro activity against the yam pathogens Curvularia eragrostides and Colletotrichum gloeosporioides. Brazilian Journal of Microbiology. v.37, n.4, p.458-461, 2006. Disponível em: $<$ http://www.scielo.br/scielo.php?script=sci_arttext\&pid=S1517$83822006000400010 \& \operatorname{lng}=$ en $\& n r m=i s o \& t \operatorname{lng}=e n>$. Acesso em: 18 abr. 2008. Doi: 10.1590/S1517-83822006000400010.

SOUSA, C.S. et al. Estreptomicetos no controle da meloidoginose em mudas de tomateiro. Pesquisa Agropecuária Brasileira, v.41, n.12, p.1759-1766, 2006. Disponível em: <http:// www.scielo.br/scielo.php? script $=$ sci arttext\&pid $=\mathrm{S} 0100$ $204 X 2006001200010 \& \operatorname{lng}=$ en\&nrm $=$ iso $\&$ tlng $=\mathrm{pt}>$. Acesso em 02 fev. 2008. Doi: 10.1590/S0100-204X2006001200010. 